\title{
SOMATIC ANTIGEN DIVERSITY IN THE GENUS SALMONELLA AS A GENETIC POLYMORPHISM
}

\author{
R. W. HEDGES \\ Bacteriology Department, Royal Postgraduate Medical School, Hammersmith \\ Hospital, London, W.12
}

Received 10.xii.70

\section{BACTERIAL POLYMORPHismS}

PolymorPHISMs for many characters have been demonstrated among the Enterobacteriaceae. The genetic bases for these are diverse. Flagellar antigens are determined by a set of multiple alleles (Iino and Lederberg 1964; McDonough, 1965). This is the simplest possible mechanism but rather unusual. A common mechanism for maintaining polymorphism is the carriage of plasmids. Examples of plasmid-determined polymorphisms are sexual differentiation (Hayes, 1953; Cavalli, Lederberg and Lederberg, 1953), colicin production (Fredericq and Betz-Bareau, 1953), resistance to antibiotics (Akiba, Koyama, Ishiki, Kimura and Fukushima, 1961), heavy metals (Smith, 1967), irradiation (Howarth, 1965), colicins (Siccardi, 1966), haemolysin (Smith and Halls, 1967) and enterotoxin production (Smith and Halls, 1968), lactose fermentation in genera normally unable to metabolise lactose (Falkow and Baron, 1962; Falkow, Wohlheiter, Citarella and Baron, 1964) and the ability to produce antigen K88 (Ørskov and Ørskov, 1966). A somewhat more complex case is provided by the genetic organisation of the restriction-modification systems. This is determined both by chromosomal polymorphism (Wood, 1966) and by plasmid-borne determinants (Lederberg, 1957; Watanabe, Nishida, Ogata, Arai and Sato, 1964; Arber, 1969). The rarity of simple chromosomally determined polymorphisms in these bacteria may reflect a low level of genetic recombination between chromosomal segments in nature (Bodmer, 1970). In the absence of such exchanges polymorphisms based upon chromosomal genes would be capable only of sluggish response to selective pressure (the whole chromosome would act as a "supergene").

\section{Somatic ANTigens in SAlmonella}

The polymorphism whose genetic determination forms the subject of this paper is the diversity of somatic antigens in the genus Salmonella. The chemical basis for the various antigenic patterns has been reviewed recently (Lüderitz, Staub and Westphal, 1966). The information in that review forms the basis of the evidence discussed in this paper.

Variability of the somatic antigen is genetically determined primarily by a chromosomal polymorphism ((at the $r f b$ operon), but an additional component of variability is conferred by the presence of phages which can effect antigenic conversion of the cells they lysogenise. The phages capable of such conversion are so diverse that it seems extremely unlikely that they are closely related. For example, although both phage $\varepsilon^{\mathbf{1 5}}$ and G341 can lysogenise Salmonella anatum and prevent the acetylation of the galactosyl 
residues of the somatic antigen, they are "not related in serological properties, host range, plaque morphology, latent period, burst size or immunity properties" (Uetake and Hagiwara, 1969).

It seems probable that the somatic antigen is extremely important in the ecology of the bacteria. Host animals can acquire resistance to reinfection by production of antibody against the somatic antigen (Roantree, 1967). It may, therefore, be an advantage for the bacterium to show as diverse an array of antigens as possible so as to avoid the effects of antibody induced by previous infections. Roantree also notes that "those Salmonella species most noted for their ability to cause disease fall into a limited number of Kauffmann-White serotypes $\left(A, B, C_{1}\right.$ and $\left.D_{1}\right)$ based on their somatic antigen formulae" and speculates that the somatic antigen repeating units may be important in withstanding polymorph and leucocyte action.

A second aspect of the ecological importance of the somatic antigens may be their role as attachment sites for phages. Thus, $S$. anatum is sensitive to a number of phages (e.g. G34l). If lysogenised with phage $\varepsilon^{15}$ the bacterium suffers a modification of the somatic antigen which confers resistance to phage G341 but renders the cell liable to attack by another set of phages (e.g. $\left.\varepsilon^{34}\right)$. This sort of situation must favour polymorphism of the somatic antigens because it is only through polymorphism that a proportion of the population can be resistant to any particular phage but does not explain why this polymorphism should have a physical basis different from that of other polymorphisms. The purpose of this paper is to propose an answer.

\section{BACTERIOPHAGE CONVERSION}

Although the converting phages are very diverse they share at least two characteristics. They are all capable of generalised transduction (Le Minor, $1965 b$ ) and many, perhaps all, absorb to the somatic antigen (i.e. to the very component that they modify). The modification of the somatic antigen means that, in many cases, the lysogenic bacterium is incapable of adsorbing superinfecting particles of the homologous phage (i.e. it is resistant as well as immune). It has been suggested that this resistance to superinfection is the most significant feature of the conversion (e.g. Boyd, 1954) but it is difficult to see why this resistance should be of advantage to either phage or host bacterium. At least one case, that of phage P22 (Stocker, Staub, Tinelli and Kopacka, 1960), is known in which the conversion does not destroy the ability of the somatic antigen to act as receptor in superinfection.

These two features of the converting phages can be taken separately. The ability to carry out generalised transduction confirms the hypothesis (Luria, 1962) that the origin of phage genomes capable of antigenic conversion is analogous to the production of transducing particles such as the $\varepsilon^{15}$ genomes capable of carrying markers derived from $R$ factors (Kameda, Harada, Suzuki and Mitsuhashi, 1965). It also confirms the notion that bacteriophages capable of generalised transduction are also capable of forming genomes into which bacterial DNA has been introduced by recombination (Hedges, 1971).

The more remarkable observation is that the converting phages all seem to adsorb to the somatic antigen. This generalisation does not seem to have been emphasised but is clearly true of phages $\varepsilon^{15}, \varepsilon^{34}$, C341 (Uetake, Luria and Burrous, 1958; Uetake and Hagiwara, 1969), P22 (Stocker et al., 
1960) and Ø20 (Baron, Formal and Washington, 1957) and seems to be the case with phages $\left.\varnothing 40_{1}, \varnothing 42, \varnothing 27, \varnothing 6,14 / 18\right)$ and $\varnothing 14(6,7)$ (Le Minor, $1962,1963,1965 a, b)$. No case of a converting phage adsorbing to a receptor other than the somatic antigen has been reported.

The most attractive explanation for this phenomenon is the notion that a converting phage can only adsorb to a bacterial cell whose somatic antigenic configuration is such that the converting potential of the phage can be usefully employed. Thus phage $\varepsilon^{34}$ adsorbs to a cell whose somatic antigen is of the $3: 15$ type, i.e. the somatic antigen consists of polymerised mannosylrhamnosylgalactose repeating units joined by $\beta$-galactosyl linkages. When introduced into a cell with such an antigenic configuration an enzyme coded for by the $\varepsilon^{34}$ genome links a glucose to the galactose of the polymer (Robbins and Uchida, 1962). This determines antigenic conversion from the $3: 15$ to the $3: 34$ type. By genetic manipulation it is possible to introduce an $\varepsilon^{34}$ prophage into $S$. anatum which has a somatic antigen of the $3: 10$ type which consists of polymerised mannosylrhamnosylgalactose with the galactose residues acetylated as repeating units joined by galactosyl linkages. In such a cell, the prophage is unable to effect conversion (Uchida, Robbins and Luria, 1963) as the glucosyltransferase of $\varepsilon^{34}$ requires a $\beta$ galactosyl residue as its substrate. Thus, the converting properties of the phage can only be expressed in a cell with an appropriate somatic antigenic configuration. If it lysogenises a cell whose somatic antigen is unsuitable to act as a substrate for the enzymes of the phage, then that phage will be unable to contribute to the antigenic polymorphism.

One can speculate further. The importance of the somatic antigen in the ecology of the bacterium has already been discussed. It is at least possible that a converting prophage in an inappropriate cell might produce enzymes having a deleterious effect on the organisation of the lipopolysaccharide layer of the cell wall. Such deleterious prophages, if they exist, might induce a phenotype approximating to that of a rough mutant. (In rough mutants the ability to produce somatic antigen is lost or reduced and the cells are at a disadvantage in several ways (Roantree, 1967).) A case that may be of this sort has been described by Makela (1966). Hfr $\times F^{-}$ crosses were performed between two species of Salmonella from different subgenera, carrying very different somatic antigens. Most of the recombinants had somatic antigens resembling one or other of the parental species, the difference being determined by a gene (or genes) in the $r f b$ cluster. A small minority of the recombinants resembled neither of the parents but were "semi-rough". Thus presumably, one of the strains carried a genetic determinant compatible with the expression of its own somatic antigen determining genes but incompatible with those of the other species. It is plausible to postulate that this determinant is a prophage especially since one of the parental strains is known to carry a converting prophage.

Regardless of whether this speculation is justified, the example shows how important it is for a bacterium to ensure the coadaption of the entire set of genes involved in specifying the organisation of the somatic antigen and shows how a gene capable of functioning satisfactorily in one genotype can fail to fit harmoniously with another set of antigenic determinants. The specificity imposed on the converting phages by their requirement for an appropriate somatic antigen as receptor accomplishes this end in an elegant manner, allowing the bacteria to maximise their spectrum of antigenic 
patterns whilst avoiding inappropriate configurations. This must be advantageous to the bacteria and hence to the symbiotic phages. Thus, if one accepts the foregoing interpretation one can understand why the somatic antigen polymorphism is organised as it is and also conclude that there would be no selective advantage for other polymorphisms to have a similar genetic organisation.

\section{Summary}

The genetic determination of somatic antigenic polymorphism is discussed and an explanation for the prophage-based component of the variability is suggested.

Acknoweledgment. - I would like to thank Dr N. Datta for assistance in the preparation of this paper.

\section{REFERENCES}

AKIBA, T., KOYAMA, K., ISHIKI, Y., KIMURA, s. AND FUKUSHIMA, T. 1961. On the mechanism of the development of multiple-drug resistant clones of Shigella. Jap. J. Microbiol., 4, 219227.

ARBER, W. 1969. Incompatibilities and restrictions in plasmid transmission. CIBA Foundation Symp. on Bacterial Episomes and Plasmids, 201-209.

BARON, L. S., FORMAL, S. B., AND WASHINGTON, o, 1957. Somatic antigen addition in Salmonella by bacteriophage. Virology, 3, 417-425.

BODMER, W. F. 1970. The evolutionary significance of recombination in prokaryotes. Symp. Soc. Gen. Microbiol., 20, 279-294. (Edited by H. P. Charles and B. C. J. G. Knight.)

BOYD, J. s. K. 1954. Bacteriophage and heredity. Nature (Lond.), 173, 1050-1051.

CAVALLI, L. L., LEDERBERG, J., AND LEDERBERG, E. M. 1953. An infective factor controlling sex compatibility in Bacterium coli. 7. Gen. Microbiol., 8, 89-103.

FALKOW, s., AND BARON, L. s. 1962. Episomic element in a strain of Salmonella typhosa. 7. Bact., 84, 581-589.

FAlKow, s., WOHLheiter, J. A., CITARElla, R. v., AND BARON, L. S. 1964. Transfer of episomic elements to Proteus. I. Transfer of $\mathrm{F}$ linked chromosomal determinants. 7 . Bact., $87,209-219$.

FREDERICQ, P., AND BETZ-BAREAUX. 1953. Transfert génétique de la propriété colicinogène chez E. coli. C.R. Soc. Biol. (Paris), 147, 1110-1113.

HAYES, w. 1953. Observations on a transmissible agent determining sexual differentiation in Bacterium coli. 7. Gen. Microbiol., 8, 72-88.

HEDGES, R. W. 1971. Transduction mechanisms of bacteriophage $\epsilon^{15}$. I. General properties of the system. Genet. Res., Camb., 17, in the press.

HOWARTH, s. 1965. Resistance to the bactericidal effect of ultra-violet radiation conferred on enterobacteria by the colicine factor, col I. 7. Gen. Microbiol., 40, 43-55.

ino, T., AND LederberG, J. 1964. Genetics of Salmonella. The World Problem of Salmonellosis. E. van Oye, editor (Dr W. Junk), 111-142.

KAMEDA, M., HARADA, K., SUZUKI, M., AND MiTSUHASHI, s. 1965. Drug resistance of enteric bacteria. V. High frequency transduction of $\mathrm{R}$ factors with bacteriophage epsilon. 7. Bact., 90, 1174-1181.

LEDERBERG, s. 1957. Suppression of the multiplication of heterologous bacteriophages in lysogenic bacteria. Virology, 3, 496-513.

LE MINOR, L. 1962. Conversion par lysogénisation de quelques sérotypes de Salmonella des groupes A, B et D normalement dépourvus du facteur $0: 27$ en cultures 27 positives. Ann. Inst. Pasteur (Paris), 103, 684-706.

LE MINOR, L. 1963. Conversions antigéniques chez les Salmonella. IV. Acquisition du facteur 01 par des Salmonella des groupes $\mathrm{R}$ et $\mathrm{T}$ sous l'effect de la lysogénization. Ann. Inst. Pasteur (Paris), 105, 879-896. 
LE minor, L. 1965a. Conversions antigéniques chez les Salmonella. VI. Acquisition des facteurs 6, 14 par les sérotypes du groups $\mathrm{K}(0: 18)$ sous l'effect de la lysogénization. Ann. Inst. Pasteur (Paris), 108, 805-811.

LE MINOR, L. 1965b. Conversions antigéniques chez les Salmonella. VII. Acquisition du facteur 14 par les Salmonella du sous-groupe $C_{1}(6,7)$, apres lysogénization par un phage tempéré isolé de cultures du sous-groupe $\mathrm{C}_{4}(6,(7),(14))$. Ann. Inst. Pasteur (Paris). $109,505-515$.

LÜDERITZ, O., STAUB, A. M., AND WESTPHAL, o. 1966. Immunochemistry of $O$ and $R$ antigens of Salmonella and related Enterobacteriaceae. Bact. Rev., 30, 192-255.

LURIA, S. E. 1962. Bacteriophage genes and bacterial functions. Science, 136, 685-692.

MCDONOUGH, M. W. 1965. Amino acid composition of antigenically distinct Salmonella flagellar proteins. 7. Molec. Biol., 12, 342-355.

MAKelA, P. H. 1966. Genetic determination of the $\mathrm{O}$ antigens of Salmonella groups $\mathrm{B}$ $(4,5,12)$ and $\mathrm{C}_{1}(6,7)$. 7. Bact., 91, 1115-1125.

øRskov, I., AND øRsKov, F. 1966. Episome carried antigen K88 of Escherichia coli. 7. Bact., 91, 69-75.

roantree, R. J. 1967. Salmonella O antigens and virulence. Ann. Rev. Microbiol., 21, 443466.

ROBBINS, P. W., AND UCHIDA, T. 1962. Studies on the chemical basis of the phage conversion of O-antigens in the E-group Salmonellae. Biochemistry (Wash.), 1, 323-335.

SICCARDI, A. G. 1966. Colicin resistance associated with resistance factors in Escherichia coli. Genet. Res., 8, 219-228.

SMTTH, D. H. 1967. $\mathrm{R}$ factors mediating resistance to mercury, nickel and cobalt. Science, $156,1114-1116$.

SMITH, H. W., AND HALls, s. 1967. The transmissible nature of the genetic factor in Escherichia coli that controls enterotoxin production. 7. Gen. Microbiol., 47, 153-161.

SMITH, H. W., AND HALLS, s. 1968. The transmissible nature of the genetic factor in Escherichia coli that controls haemolysin production. 7. Gen. Microbiol., 52, 319-334.

STOCKER, B. A. D., STAUB, A. M., TINELLI, R., AND KOPACKA, B. 1960. Etude immunochimique sur les Salmonella. VI Étude de l'antigèn I présent sur deux Salmonella des groupes B et E. Ann. Inst. Pasteur (Paris), 98, 505-523.

UCHIDA, T., ROBBINS, P. W., AND LURIA, S. E. 1963. Analysis of the serological determinant groups of the Salmonella E-group O-antigens. Biochemistry (Wash.), 2, 663-668.

UETAKE, H., AND HAGTWARA, s. 1969. Transfer of conversion gene(s) between different Salmonella phages G341 and $\varepsilon^{15}$. Virology, 37, 8-14.

uetake, H., LURIA, s. E., AND BURrous, J. W. 1958. Conversion of somatic antigens in Salmonella by phage infection leading to lysis or lysogeny. Virology, 5, 68-91.

watanabe, T., NISHIDA, H., OgAtA, 4., ARAI, T., AND sATo, s. 1964. Episome-mediated transfer of drug resistance in enterobacteriaceae. VII. Two types of naturally occurring $\mathrm{R}$ factors. 7. Bact., 88, 716-726.

wooD, w. B. 1966. Host specificity of DNA produced by Escherichia coli: bacterial mutations affecting the restriction and modification of DNA. 7. Molec. Biol., 16, 118-133. 